\title{
SOIL ELECTRICAL RESISTIVITY MAPPING IN THE FORMOSA CITY LANDFILL, GOIÁS STATE, BRAZIL
}

\author{
Wilyane Silva Figueiredo and Carlos Tadeu Carvalho do Nascimento
}

\begin{abstract}
The purpose of this work was to study the surroundings of a landfill in the Formosa city, Goiás state, central Brazil, with respect to the values of the soil electrical resistivity. In the study area, two geophysical surveys were conducted, respectively in 2012 January and May. These studies were executed in the northwest edge of the landfill, which has smaller altimetry and therefore is the preferred site for effluents migration. The resistivity variation in the study area between the two data acquisition periods showed an average increase of approximately $47 \%$ in the value of this property in the transition from the rainy to the dry season. Independent of variation derived from the seasonal aspects of precipitation, there were observed areas with high and low resistivity along the survey line and whose positions are the same in both periods. The reasons for the occurrence of these areas are related to surface water runoff, which transports material in solution from landfill, including nearby roads, to its slope.
\end{abstract}

Keywords: geophysical survey, effluent migration, surface water runoff.

RESUMO 0 objetivo deste trabalho foi estudar o entorno do Aterro Sanitário de Formosa, estado de Goiás, Brasil, mais especificamente sua borda noroeste, no que diz respeito aos valores da resistividade elétrica do solo. Na área de estudo foram realizados dois levantamentos geofísicos, respectivamente em janeiro e maio de 2012. Estes levantamentos foram executados na região noroeste do aterro, a qual apresenta as menores cotas e, portanto, é o local preferencial para migração de efluentes. A variação da resistividade na área de estudo entre os dois períodos de aquisição de dados mostrou que em média ocorreu um aumento de aproximadamente $47 \%$ no valor desta propriedade na passagem da estação chuvosa para a de seca. Independente da variação derivada dos aspectos sazonais de precipitação observaram-se, nos períodos de levantamento, áreas com alta e baixa resistividade ao longo da linha de aquisição de dados e cujas posições são coincidentes nos dois períodos. A justificativa para a ocorrência destas zonas está vinculada ao escoamento superficial de água, a qual, ao escoar na área do aterro, inclusive pelas estradas ali existentes, transporta material em solução que tende a se acumular no seu talude.

Palavras-chave: levantamentos geofísicos, migração de efluente, escoamento superficial. 


\section{INTRODUCTION}

The sharp increase in solid waste generation and its spatial concentration due to urbanization, affects how they are broken down by the environment. Improper disposal of them can cause many negative impacts on the physical environment as the landscape changes, air pollution and increased risk of landslides in areas with steep topography, soil contamination, groundwater and springs by effluent from waste. (Castilhos Júnior, 2006).

In most Brazilian cities, the circuit of solid waste has very similar characteristics, involving the regular collection, transportation and final disposal in landfills, often selected by the availability of areas, the distance from the city center and the access roads (Schalch et al., 2002).

In Formosa city, Goiás state, central Brazil, waste is disposed in a landfill, which began operating in 1997 and is located about five kilometers north of the city and upstream of the source of a watercourse. On the assumption of existing some effluent leak originated from the landfill in the subsurface, the possibility of groundwater contamination would exist either (Goiás, 2003).

Geophysical methods are important research tools for to investigate soils and rocks characteristics. This determination is based on the measuring of physical parameters such as electrical resistivity, density and magnetic susceptibility. They are widely used in mineral prospecting and geological mapping and since 1970 also for environmental monitoring (Gallas et al., 2001; Silva et al., 2002; Laureano \& Shiraiwa, 2008; Bortolin \& Malagutti Filho, 2009; Costa \& Malagutti Filho, 2009; Cavalcanti et al., 2011; Oliveira \& Moreira, 2011).

Malagutti Filho \& Silva (2009) argue that geophysical studies provide the attainment of continuous outlines, which allow it to identify with greater precision the lateral variation, resulted from lithological variations or caused by the presence of groundwater contaminants.

The versatility and simplicity of application of geophysical methods, the minimally invasive nature, the rapid evaluation of large areas coupled with low operating costs when compared to other forms of direct investigation, make them excellent tools that aid in environmental studies (Lago et al., 2006; Bortolin \& Malagutti Filho, 2011; Oliveira \& Moreira, 2011).

In general, the contaminants founded in the regions of garbage dumps and landfills have higher conductivity values when compared with the host rocks and local soils. Mapping can be accomplished by providing information on the natural soil profile, depth of the saturated zone and the bedrock, groundwater flow direction (Lago et al., 2006; Costa \& Malagutti Filho, 2009; Rocha \& La Terra, 2011).
According to Moreira \& Braga (2009) the composition of the leachate in the landfill or dump depends on several factors such as type and age of the deposited waste, rate of water infiltration and soil pH. Furthermore, the amount of gas and leachate materials may be affected by the depth of waste disposal, climate conditions, ground water level, thickness of the coating material, fluids migration in the area (Farquhar, 1989).

The main bounding of the landfill object of this work is the highway G0-430, positioned on the northeast of the area of waste disposal. The altitude (meters) for the landfill area varies between 974 in the northern portion and 1017 in the southern portion (Fig. 1).

The study area, included in the Cerrado region, presents an Aw tropical climate, defined by Koppen as a savannah climate with an average temperature of $22^{\circ} \mathrm{C}$, average monthly evapotranspiration of $65 \mathrm{~mm}$ and annual rainfall of approximately $1500 \mathrm{~mm}$, distributed mostly between October and March (Maia \& Baptista, 2008).

The Paranoá and Bambuí groups are the most important geological units of the study area. The Paranoá Group is interpreted as a sequence of metasedimentary rocks (metargilites, metasiltstone and quartzites), deposited in a shallow marine environment, predominantly transgressive, during the Mesoproterozoic. The Bambuí Group of Neoproterozoic age consists of metasiltstone, metargilites, carbonate rocks and rare intercalations of arkose. In the study area only a soil coverage was observed, not rocky outcrops.

The landfill of Formosa city has around $250000 \mathrm{~m}^{2}$ in use currently. The beginning of the activities took place in 1997 and the expected life goes until 2017. Operating system essentially consists of the landfill disposal garbage in ditches measuring 4 to 6 meters. These trenches receive waste for a period ranging from 10 to 15 days and are finally covered with a layer of soil with $80 \mathrm{~cm}$ thick. There is no separation or recycling of materials, all household and commercial wastes collected in the city have the landfill as a common destination.

In this work we performed a geophysical study in the vicinity of the landfill, more specifically in the topographically lower area (west edge). We applied the DC electrical resistivity method in order to identify areas of low electrical resistivity, which could indicate the migration of leachate from the landfill.

\section{METHODOLOGY}

In the DC electrical resistivity method, we work with two current electrodes ( $A$ and $B$ ) and two potential electrodes ( $M$ and $N$ ), all four set out on the soil surface. Through electrodes A and B, we 


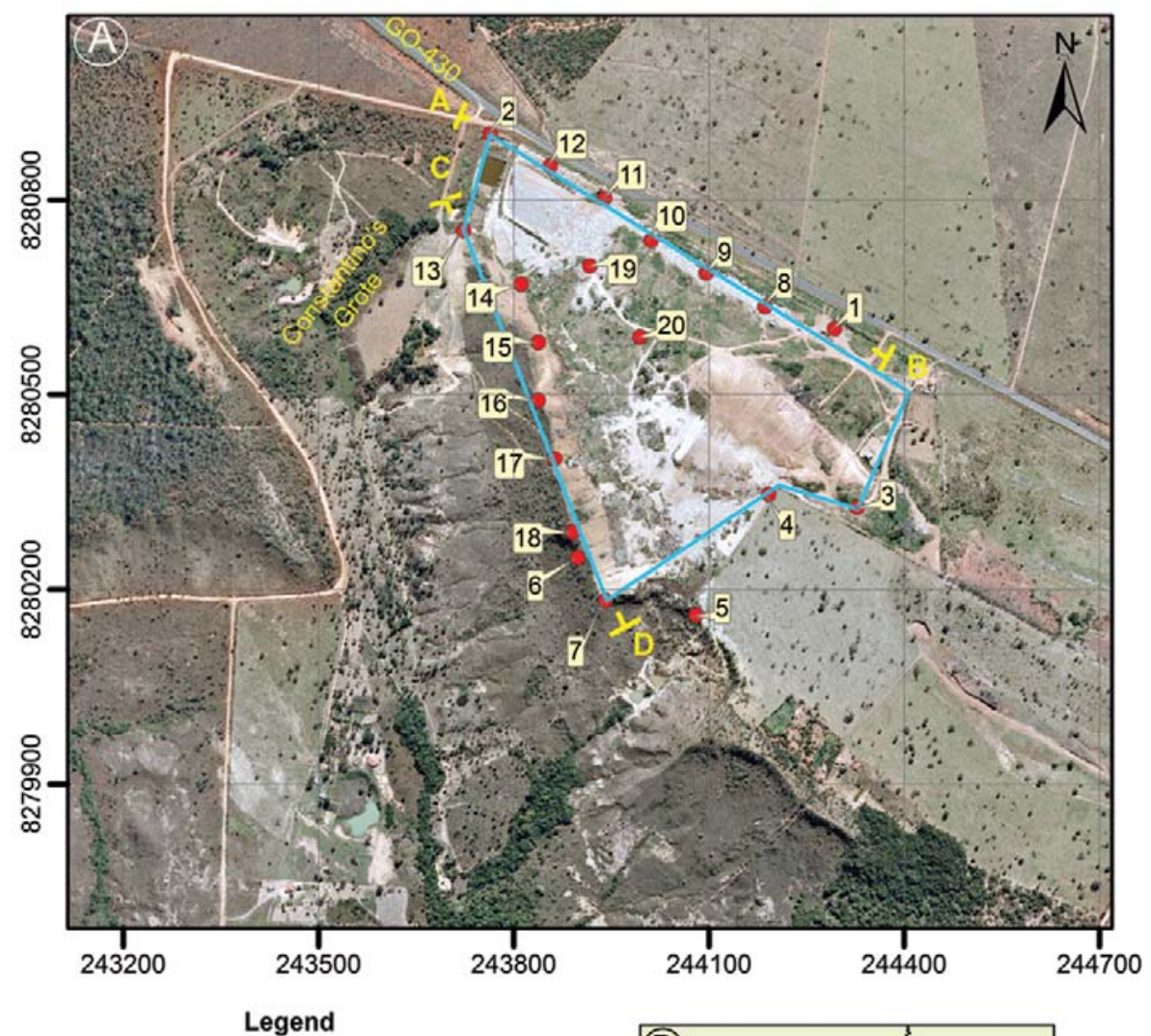

- Points of control

Area in use $-258392 \mathrm{~m}^{2}$

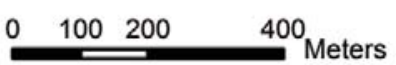

Source: SEDHAB, 2010a, b

Projection: UTM

Datum: SAD-69

Zone: $23 \mathrm{~L}$
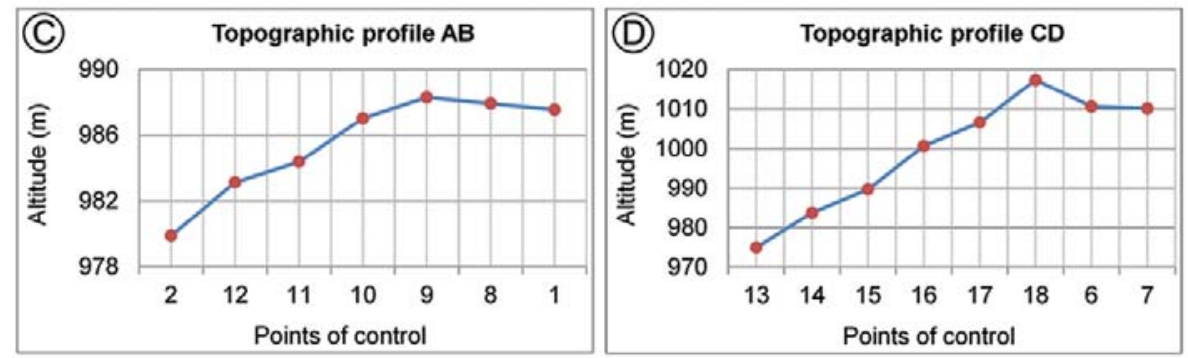

Figure 1 - Points of control for purposes of planialtimetric study of the Formosa city landfill. A) Details of the study area; B) Location of the study area in the state of Goiás; C) Topographic profile AB; D) Topographic profile CD.

apply a potential difference, and as a result of this difference, a continuous electrical current begins to traverse the terrain. The value of the current is measured and recorded. Using electrodes $\mathrm{M}$ and $\mathrm{N}$, we measure a potential difference that is established in the field and is associated with the passage of current. It should be noted that the soil already has a natural electric potential, which should be subtracted from the measurement made with electrodes $\mathrm{M}$ and $\mathrm{N}$. 
Based on the current flowing through the subsoil, the geometry of the arrangement of electrodes and the potential measured between electrodes $\mathrm{M}$ and $\mathrm{N}$, one can calculate an electrical resistivity value. This value, measured in a heterogeneous and anisotropic medium and as a function of the electrode array, is known as the apparent resistivity. The most frequent cause of change in value of resistivity in soils and rocks is the water content. The larger the volume of water with material in solution, the lower the resistivity (Orellana, 1972; Telford et al., 1990).

There are several ways to arrange and carry the electrodes in the area being studied. In this work, we adopted the Wenner array, which consists of equidistant potential and current electrodes in a straight line layout, positioning the electrodes $A$ and $B$ at the ends of the array, while $\mathrm{M}$ and $\mathrm{N}$ are located near the center (Nascimento et al., 2004). The choice of this arrangement gave up due to its suitability to detect lateral variations in resistivity and practicality with regard to the acquisition of measurements. Eq. (1) shows how to calculate the apparent resistivity with this arrangement. In this equation $\rho_{a}$ is the apparent resistivity, $a$ is the electrode spacing, $i$ is the amount of current going through the soil and $d d p$ is the potential that lays on the ground during the current flow, discounted from the natural potential.

$$
\rho_{a}=2 \cdot \pi \cdot a \cdot \frac{d d p}{i}
$$

The horizontal electrical profiling technique is based on performing measurements of apparent resistivity, where the four electrodes ( $A, B, M$ and $N$ ) are moved simultaneously on the ground in order to obtain a set of regularly distributed data (Malagutti Filho \& Silva, 2009). In this method, it is assumed that the depth of investigation is directly proportional to the electrode spacing. Therefore, keeping constant this distance it is assumed that the depth of investigation is the same throughout the study.

In this work, two geophysical studies were performed on an unpaved road located at the northwest edge of the Formosa city landfill. In January 2012, the local rainy season, data were obtained along a 300 meters line, using the Wenner array with a spacing of 10 meters between electrodes, totaling 28 resistivity measurements. In May 2012, when there is almost rainless, the same procedure was performed in order to identify the effect of reduced soil moisture due to lower rainfall volume in the distribution of resistivity values in the study area. The horizontal electric profiling was performed using a resistivimeter Pergeo ER-300.

The choice of the location to conduct the surveys considered the topographical features of the region. The lower area is the preferred location for concentration of leachate from the landfill. The Figure 2 corresponds to the elevation model of the landfill area, generated from altimetric data from SRTM - Shuttle Radar Topography Mission (Miranda, 2005). In this Figure, runoff vectors are represented in addition to the elevation values.

Some types of information need to have your data sorted and distributed into smaller sets to reach the correct understanding of its meaning (Ferreira, 2001). Thus, in the present study apparent resistivity data were classified by Sturges' formula Eq. (2) where $n$ is the number of resistivity measurements, and $K$ is the number of classes.

$$
K=1+3,3 \cdot \log _{10} n
$$

After determination of $K$, subtraction must be performed between the highest and lowest value in the data set, dividing the subtraction result by the number of classes, this way is obtained the class interval, which is used for establish the lower and upper limits of each class.

\section{RESULTS}

In January 2012 (rainy season) and in May 2012 (dry season) the values of apparent resistivity for the 28 points were obtained (Fig. 3).

The results of the horizontal electric profiling, held in January 2012, revealed that along the studied line the average resistivity was 1261 Ohm.m, and point 9 presented the highest value (437 Ohm.m) and point 24 was the one with the lowest value (259 Ohm.m).

The profiling results in May 2012 revealed that on average resistivity was 1855 Ohm.m, being the point 10 which showed the highest (3140 0hm.m) and point 28 which showed the lowest value (628 0hm.m).

Considering the two surveys, the highest values occur between points 7 and 10, suggesting the presence of more resistive materials in the subsurface.

In rainy season the resistivity values are relatively low and shows high variability with standard deviation 912.21. During the dry season these values show up higher and more uniform with standard deviation 578.77 (Fig. 3).

The apparent resistivity data were classified by the Sturges' formula. In both analyzed periods, classes were separated into different colors according to the ranges of resistivity values. Figures 4 and 5 shows the classification of the resistivity values measured in January and May 2012, respectively. It can be observed that the points belonging to class 1 (red color), have the lower values, range between 259 and 944 0hm.m in January and between 628 and 1045 Ohm.m in May. 


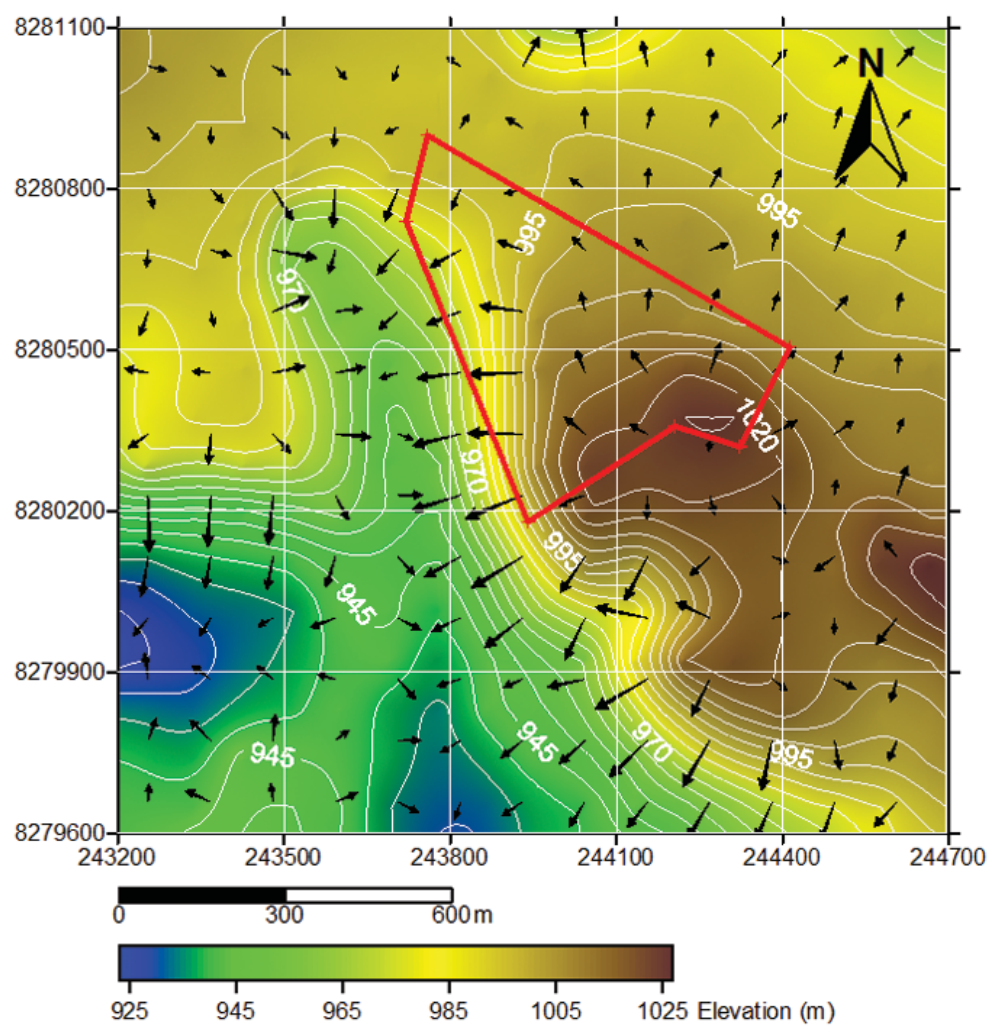

Figure 2 - Elevation model of the Formosa City Landfill.

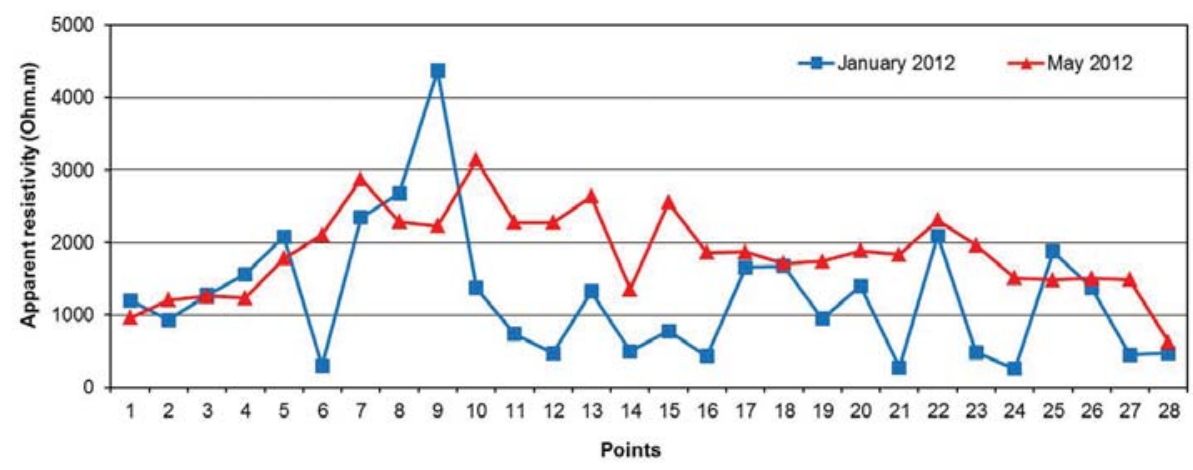

Figure 3 - Electrical resistivity values recorded in January 2012 (rainy season) and May 2012 (dry season).

\section{DISCUSSION}

An increasing resistivity average between January and May 2012 could be observed in the study area, confirming the expected behavior for this region in the transition from the rainy to the dry season, meaning an increase in the electrical resistivity of the soil.

The electric profiling performed in January, on the landfill downstream road, had characterized by values with little uniformity, and less resistive region was between points 11 and 16 (Fig. 4). This fact can be justified by the existence of the Constantino's Grote intermittent drainage tributary, which according to the relative abundance of water derived from rains facilitated the accumulation of moisture in the soil, lowering the resistivity. As punctual evidence of the existence of surface runoff in this region, there is a duct under the road. In the place of this duct, which corresponded to the point 12 in January was recorded one of the lowest resistivity values (476 $0 \mathrm{hm} . \mathrm{m}$ ), precisely because of the water flow.

Moreover, it was observed that between points 1 and 10 the resistivity is higher than that recorded between points 17 and 28. In this profiling region, the low resistivity values can be 


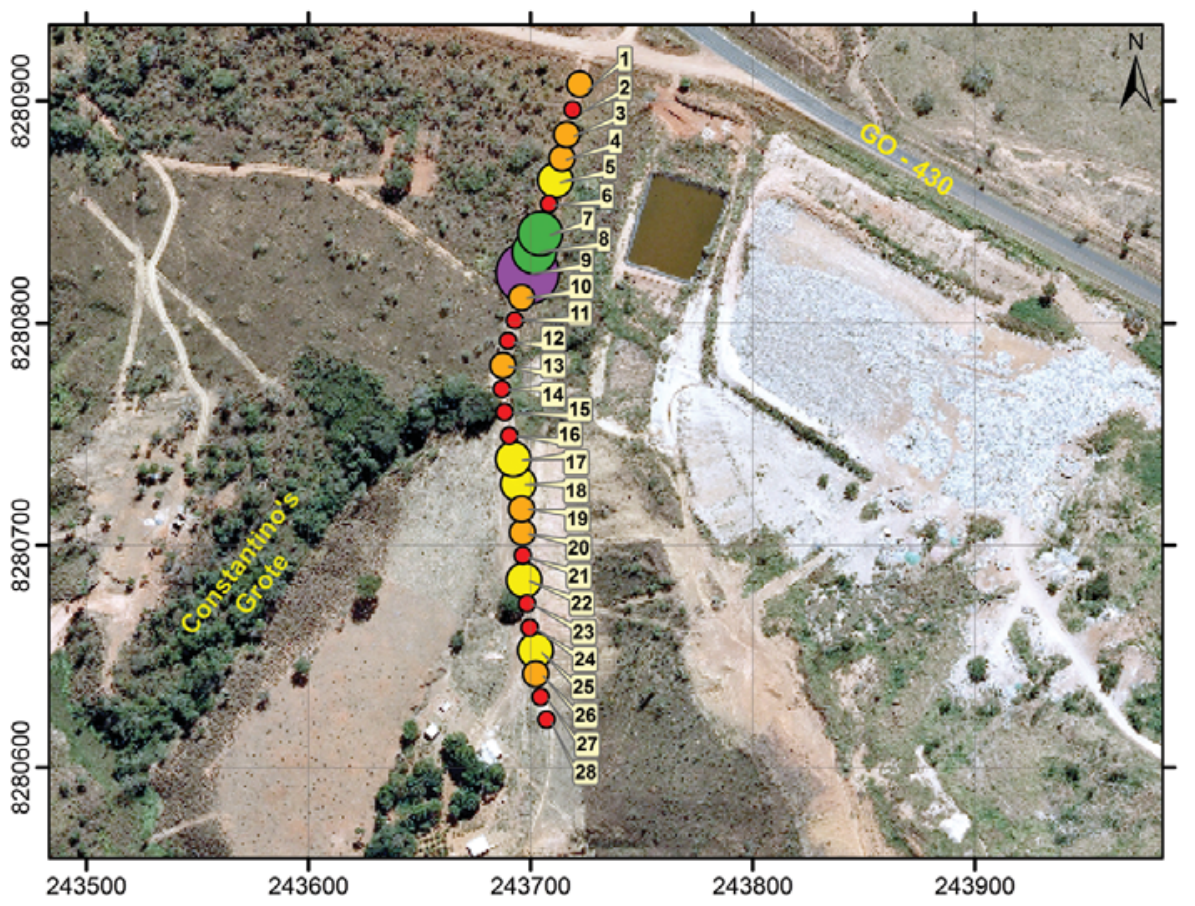

Figure 4 - Thematic map of resistivity in January 2012.

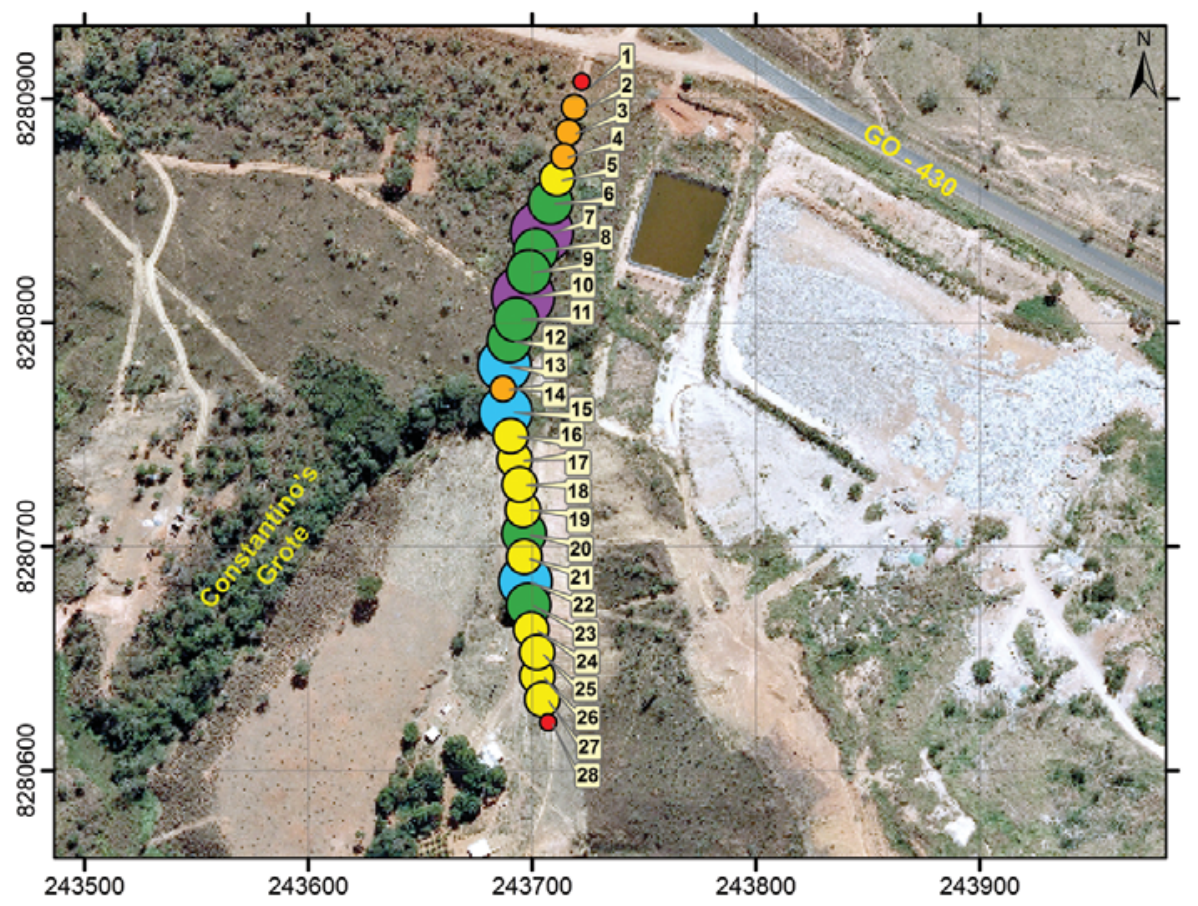

Figure $\mathbf{5}$ - Thematic map of resistivity in May 2012.
Legend

Classification of the resistivity values at each measurement point

$\begin{array}{ccc}\text { Class } & \text { Symbol } & \text { Interval } \\ 1 & \bigcirc & {[259-944]} \\ 2 & \bigcirc & {[945-1630]} \\ 3 & \bigcirc & {[1631-2316]} \\ 4 & \bigcirc & {[2317-3002]} \\ 5 & \bigcirc & {[3003-3688]} \\ & & \\ 6 & \bigcirc & {[3689-4374]}\end{array}$

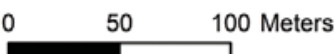

Source: SEDHAB, 2010a, b Projection: UTM Datum: SAD-69 Zone: $23 \mathrm{~L}$

Classification of the resistivity values at each measurement point

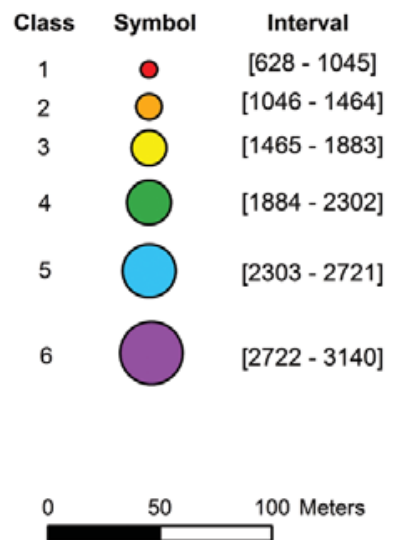

Source: SEDHAB, 2010a, b

Projection: UTM

Datum: SAD-69

Zone: $23 \mathrm{~L}$

justified because it is a topographically lower region (elevation $956 \mathrm{~m}$ in point 17), where the water that flows superficially through the landfill surface concentrate (elevation $983 \mathrm{~m}$ in point 14) and thus will also have more moisture in the rainy season.
The electric profiling performed in May was characterized by more uniform values in relation to profiling done in January, and it is possible to identify two regions respectively more and less resistive, the first between points 1 and 16 and the second 


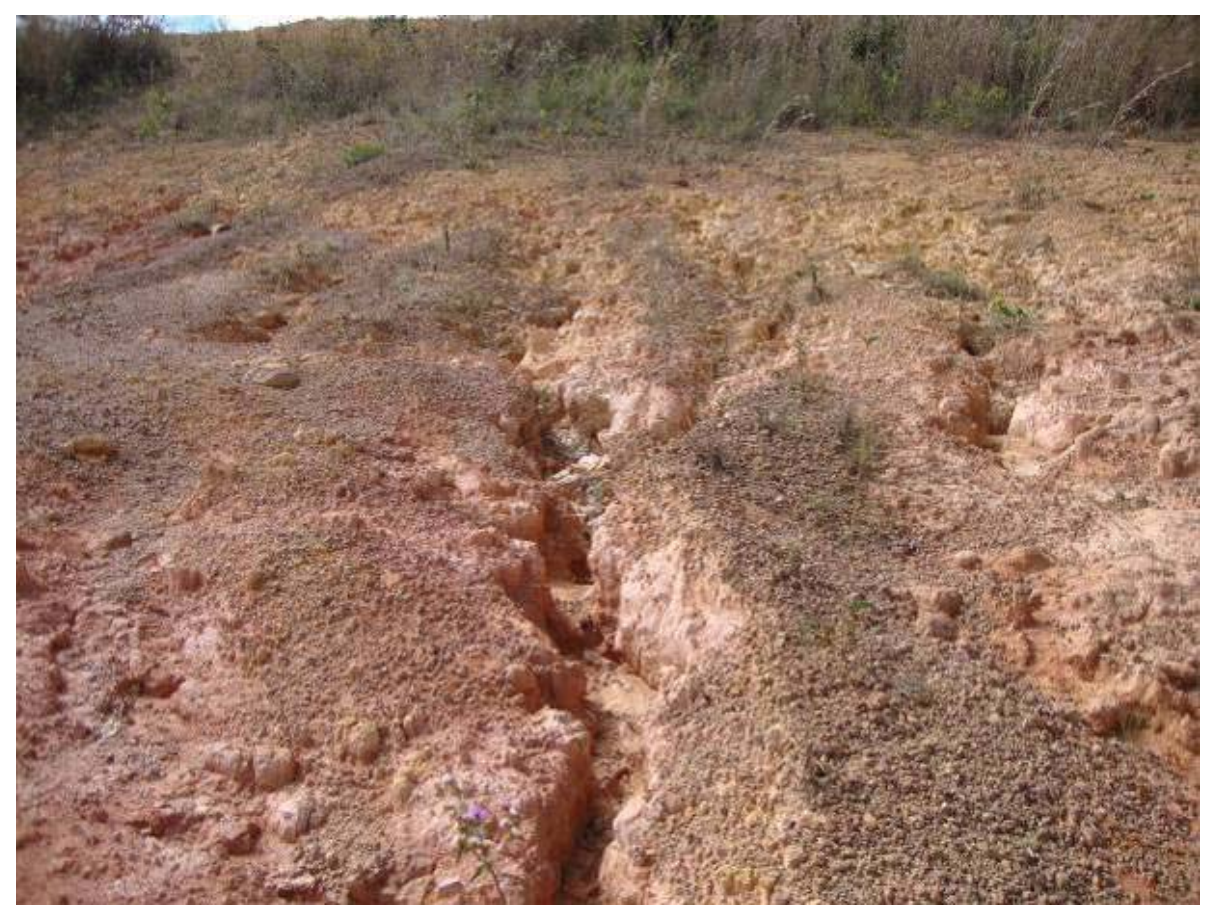

Figure 6 - Erosion on northwest edge of Formosa City Landfill.

between points 17 and 28 (Fig. 3). This behavior can be explained by the management strategy for the landfill area over time. It is observed in Figure 6 that in the region contained between points 17 and 28 erosive processes occur. These processes should be linked to the water runoff whose source is precisely the region of the landfill. This water that should preferably flow by roads built for the passage of garbage trucks, focuses on the lowest part of the landfill. Given the impossibility of it flowing into the manure lagoon due to the heightening of its edges, the water flows through the landfill slope toward the road where profiling was performed exactly in the region between points 17 and 28 . There is the possibility that, over time, this runoff has led to the accumulation of salts in the region between points 17 and 28.

\section{CONCLUSIONS}

The resistivity contrast in the study area between the two periods of data acquisition showed an average increase of approximately $47 \%$ in the value of this property in the transition from the rainy to the dry season.

Regardless of the variation linked to the seasonal aspects of precipitation, during periods of surveys were observed areas with high and low resistivity along the data acquisition line and whose positions are the same in both periods.

The arrangement and spacing between electrodes adopted in the surveys enabled to accurately delimit the most conductive and therefore potentially polluted areas.
An area of low resistivity was observed between points 17 and 28. Such low values can be explained mainly by runoff on the slope of the landfill, which is responsible for erosion on the site.

The DC electrical resistivity method was used in this work for indirect subsoil research. Although the results of the surveys and the analysis of local environmental conditions have allowed the identification of a possibly polluted area, it does not exclude the need to direct research to confirm this pollution. Direct research strategies could include, for example, collecting and chemical analysis of soil for proving its salinization.

\section{ACKNOWLEDGEMENTS}

The authors thank the Laboratory of Applied Geophysics of Universidade de Brasília for geophysical equipment; the Laboratory of Environmental Monitoring and Analysis of Universidade de Brasilia for GPS equipment; the Formosa City Landfill Administration that authorized the field studies; the Formosa City Department of Transportation for providing information about the landfill.

\section{REFERENCES}

BORTOLIN JRM \& MALAGUTTI FILHO W. 2009. Monitoramento temporal da pluma de contaminação em aterro controlado, na cidade de Rio Claro (SP), por meio do método da eletrorresistividade. In: International Congress of the Brazilian Geophysical Society, 11., 2009, Salvador. Proceedings... Salvador, Brazil: SBGf, 2009. CD-ROM. 
BORTOLIN JRM \& MALAGUTTI FILHO W. 2011. Monitoramento temporal de contaminação por chorume usando métodos geoelétricos. In: International Congress of the Brazilian Geophysical Society, 12., 2011, Rio de Janeiro. Proceedings... Rio de Janeiro, Brazil: SBGf, 2011. CD-ROM.

CASTILHOS JÚNIOR AB. 2006. Gerenciamento de resíduos sólidos urbanos com ênfase na proteção de corpos d'água: prevenção, geração e tratamento de lixiviados de aterros sanitários. Rio de Janeiro, Brazil: Abes, 494 pp.

CAVALCANTI MM, BORGES WR, ROCHA MP, CUNHA LS \& SEIMETZ EX. 2011. Investigação Geofísica (Eletrorresistividade e GPR) nos Limites do Lixão da Estrutural e do Parque Nacional de Brasília - DF (Resultados Preliminares). In: International Congress of the Brazilian Geophysical Society, 12., 2011, Rio de Janeiro. Proceedings... Rio de Janeiro, Brazil: SBGf, 2011. CD-ROM.

COSTA AF \& MALAGUTTI FILHO W. 2009. Aplicação de sondagens elétricas verticais no estudo da contaminação na lixeira de Porto Velho (R0). In: International Congress of the Brazilian Geophysical Society, 11. 2009, Salvador. Proceedings... Salvador, Brazil: SBGf, 2009. CD-ROM.

FARQUHAR GJ. 1989. Leachate: production and characterization. Can. J. Civ. Eng., 16: 317-325.

FERREIRA LDA. 2001. Estatística Descritiva. Salvador: Universidade Federal da Bahia, Instituto de Matemática, Departamento de Estatística, Bahia, Brazil. 35 pp. Available on: <http://www.est.ufba.br/mat027/ mat027apostila1.pdf>. Access on: March 24, 2012.

GALLAS JDF, TAIOLI F, MALAGUTTI FILHO W, PRADO RL \& DOURADO JC. 2001. Métodos e técnicas geoelétricas rasas na delimitação de área afetada por ruptura em teto de túnel urbano. Brazilian Journal of Geophysics, 19(1): 33-46.

GOIÁS. 2003. Plano diretor do município de Formosa/GO. Goiás, Brazil. $44 \mathrm{pp}$.

LAGO AL, ELIS VR \& GIACHETI HL. 2006. Aplicação integrada de métodos geofísicos em uma área de disposição de resíduos sólidos urbanos em Bauru-SP. Brazilian Journal of Geophysics, 24(3): 357-374.

LAUREANO AT \& SHIRAIWA S. 2008. Ensaios geofísicos no aterro sanitário de Cuiabá-MT. Brazilian Journal of Geophysics, 26(2): 173180.

MAIA JMF \& BAPTISTA GMM. 2008. Clima. In: FONSECA FO (Org.). Águas Emendadas. Brasília, Brazil: Secretaria de Desenvolvimento Urbano e Meio Ambiente. pp. 101-110.

MALAGUTTI FILHO W \& SILVA RWC. 2009. Emprego do método da eletrorresistividade no estudo da contaminação subsuperficial do cemitério de Piracicaba - SP. In: International Congress of the Brazilian Geophysical Society, 11., 2009, Salvador. Proceedings... Salvador, Brazil: SBGf, 2009. CD-ROM.

MIRANDA EE. 2005. Brasil em Relevo, Carta SD 23. Campinas: Embrapa Monitoramento por Satélite. Available on: <http://www.relevo. cnpm.embrapa.br>. Access on: March 19, 2012.

MOREIRA CA \& BRAGA AC0. 2009. Anomalias de cargabilidade em aterro de resíduos sólidos domiciliares. Brazilian Journal of Geophysics, 27(1): 55-62.

NASCIMENTO CTC, PIRES ACB \& MORAES RAV. 2004. Reconhecimento de solos por meio de resistividade elétrica e radiação gama. Revista Brasileira de Geociências, 34(3): 383-392.

OLIVEIRA MT \& MOREIRA CA. 2011. Aplicação do método de Polarização Induzida em área de disposição de resíduos sólidos no município de Caçapava do Sul - RS. In: International Congress of the Brazilian Geophysical Society, 12., 2011, Rio de Janeiro. Proceedings... Rio de Janeiro, Brazil: SBGf, 2011. CD-ROM.

ORELLANA E. 1972. Prospeccion Geoelectrica en Corriente Continua. Madrid: Paraninfo. 523 pp.

ROCHA LF \& LA TERRA EF. 2011. Uso do método TDEM (eletromagnético no domínio do tempo) na investigação de pluma de contaminação. In: International Congress of the Brazilian Geophysical Society, 12., 2011, Rio de Janeiro. Proceedings... Rio de Janeiro, Brazil: SBGf, 2011. CD-ROM.

SCHALCH V, LEITE WCA, FERNANDES JÚNIOR JL \& CASTRO MCAA. 2002. Gestão e gerenciamento de Resíduos Sólidos. São Carlos, Brazil: EESC-USP. Available on: <http://www.deecc.ufc.br/Download/ Gestao_de_Residuos_Solidos_PGTGA/Apostila_Gestao_e_Gerenciamento_de_RS_Schalch_et_al.pdf>. Access on: March 20, 2012.

SEDHAB - Secretaria de Habitação, Regularização e Desenvolvimento Urbano. 2010a. Ortofotocarta 28. Brasília, Brazil. Available on: <http://www.sedhab.df.gov.br/mapas_sicad/index_sirgas.htm>. Access on: Sept. 21, 2012.

SEDHAB - Secretaria de Habitação, Regularização e Desenvolvimento Urbano. 2010b. Ortofotocarta 43. Brasília, Brazil. Available on: $<$ http://www.sedhab.df.gov.br/mapas_sicad/index_sirgas.htm>. Access on: Sept. 21, 2012.

SILVA JE, LOUREIRO EML, ELIS VR, HIODO FY \& PORSANI JL. 2002. Aplicação de ensaios elétricos e eletromagnéticos em problema de poluição ambiental. Brazilian Journal of Geophysics, 20(3): 193-198.

TELFORDWM, GELDART LP \& SHERIFF RE. 1990. Applied Geophysics. 2nd ed., Cambridge: Cambridge University Press. 770 pp. 


\section{NOTES ABOUT THE AUTHORS}

Wilyane Silva Figueiredo is undergraduated in Environmental Management (UnB - 2012), nowadays attending to the masters degree course in Environmental and Rural Development at the Universidade de Brasilia. Is an expert in GIS and risk assessment related to human exposure to mercury and other trace elements studies.

Carlos Tadeu Carvalho do Nascimento is undergraduated in Geology (UnB - 1993), M.Sc. in Environmental Technology and Water Resources (UnB - 1998) and Ph.D. in Geology (UnB - 2003). Currently, is a professor at the Universidade de Brasilia, Planaltina Campus. Is an expert in Geosciences with emphasis on Applied Geophysics, working mainly in the environmental area. 